\title{
Endokrinoloji Kliniği'nde Yatan Diyabetik Hastaların Anemi Yönünden Değerlendirilmesi
}

\author{
Evaluation of Diabetic Inpatients in Endocrinology Clinic in Terms of Anemia
}

Eskişehir Osmangazi Üniversitesi Tip Fakültesi, Endokrinoloji Bilim Dalı, Eskişehir, Türkiye

Correspondence:

Bilge BAŞDOĞAN

Eskişehir Osmangazi Üniversitesi Tip Fakültesi, Endokrinoloji Bilim Dalı, Eskișehir, Türkiye

e-mail: blg020@hotmail.com

\section{Bilge Başdoğan, Özge Özer, Fatma Belgin Efe, Ahmet Toygar Kalkan, Nur Kebapçı,}

Aysen Akalın, Göknur Yorulmaz

\section{Özet}

Anemi, diyabetik hastalarda sık görülen bir bulgudur. Diyabetik hastalarda anemiye neden olan birden çok faktör vardır. Anemi, diyabetik komplikasyonların ilerlemesine yol açarak önemli bir morbidite nedeni olabilmektedir. Bu çalışmada, diyabetik hastalarda anemi sıklığını ve anemiye eşlik eden faktörleri araşıırmayı amaçladık. Ocak 2019 ile Ocak 2020 arasında Eskişehir Osmangazi Üniversitesi Hastanesi Endokrinoloji Kliniğinde yatan 194 diyabetik hasta retrospektif olarak incelendi. Hastaların demografik özellikleri, ilaçları, laboratuvar sonuçları ve komplikasyonlar kaydedildi. Anemi erkeklerde hemoglobin $(\mathrm{hb})<13 \mathrm{~g} / \mathrm{dl}$ ve kadınlarda $\mathrm{hb}<12 \mathrm{~g} / \mathrm{dl}$ konsantrasyonları olarak tanımlandı. Anemiye neden olacak ek hastalığı olanlar (hematolojik hastalık, maligniteler, gastrointestinal hastalıklar) çalısmaya dahil edilmedi. Diyabetik hastaların \%33'ünde anemi vard. Anemisi olan ve olmayan gruplarda cinsiyet dağılımları benzerdi $(\mathrm{p}=0.89)$. Hastalar glomerüler filtrasyon hızına (GFR) göre kategorize edildiğinde GFR azaldıkça anemi oranının arttığı izlendi $(p=0.003)$. Albüminüri düzeyi ile anemi arasında iliski saptanmadı $(p=0.22)$. Diyabetik ayak sorunu ile anemi arasında anlamlı bir ilişki izlendi $(p=0.004)$. Calışmamızda diyabetik hastalarda anemi prevalansı yüksekti. Diyabetik ayak sorunu olanlarda anemi daha sık izlendi. Diyabetik hastalarda hayat kalitesini artırmak ve aneminin getirebileceği ek sorunları önlemek açısından bu grup hastalarda anemi erken teşhis ve tedavisi önemlidir

Anahtar Kelimeler: Anemi; diyabet; diyabetik ayak yaras

\section{Abstract}

Anemia is a common finding in diabetic patients. There are multiple factors that cause anemia in diabetic patients. Anemia can be an important cause of morbidity by leading to the progression of diabetic complications. In this study, we aimed to investigate the frequency of anemia and the factors accompanying anemia in diabetic patients. 194 diabetic patients hospitalized in Eskisehir Osmangazi University Hospital Endocrinology Clinic between January 2019 and January 2020 were retrospectively analyzed. Demographic characteristics, medications, laboratory results and complications of the patients were recorded. Anemia was defined as hemoglobin $(\mathrm{hb})<13 \mathrm{~g} / \mathrm{dl}$ in men and $\mathrm{hb}<12 \mathrm{~g} / \mathrm{dl}$ in women. Those with additional diseases that would cause anemia (hematological disease, malignancies, gastrointestinal diseases) were not included in the study. Anemia was present in $33 \%$ of diabetic patients. Gender distributions in the groups with and without anemia were similar $(p=0.89)$. When the patients were categorized according to their glomerular filtration rate (GFR), it was observed that as the GFR decreased, the rate of anemia increased $(p=0.003)$. There was no relationship between albuminuria level and anemia $(p=0.22)$. A significant relationship was observed between diabetic foot problem and anemia $(p=0.004)$. In our study, the prevalence of anemia was high in diabetic patients. Anemia was observed more frequently in patients with diabetic foot problems. Early diagnosis and treatment of anemia is important in this group of patients in order to improve the quality of life in diabetic patients and to prevent additional problems that may be caused by anemia.

Keywords: Anemia; diabetes; diabetic foot ulcer

Received 09.11.2020 Accepted 17.05.2021 Online published 18.05.2021 


\section{Giriș}

Diyabet, artan sıklığı nedeniyle tüm dünyada önemli bir sağllk sorunu haline gelmiştir. Günümüzde, yılda yaklaşık 4.2 milyon yetişkinin diyabet ve komplikasyonları nedeniyle hayatını kaybettiği tahmin edilmektedir (1). Anemi, başta demir eksikliği olmak üzere birçok nedene bağlı olarak görülebilen sık bir bulgudur. Anemi, gelişme süresi ve şiddetine bağlı olarak hastalarda semptomatik olabilse de birçok hastada asemptomatik seyirli ve rutin laboratuvar testleri ile $\tan 1$ koyulan bir durumdur. Diyabetik hastalarda anemi s1klığ kökenlerde \%11.5 ile \%45 arasında değişen yüzdelerde saptanmıştır (2-4). Diyabetiklerde anemi diyabetik olmayanlara göre daha s1k görülmektedir (5). Buna neden olan en önemli faktör diyabetik böbrek hastalığ birlikteliğidir. Böbrek peritübüler hücrelerinden salgilanan EPO (eritropoetin) doku hipoksisine yanit olarak eritroid progenitör hücreleri uyaran bir büyüme faktörüdür. Kronik böbrek hastalı̆̆ında (KBH) EPO salgilayan hücrelerin hasarına bağlı olarak renal yetmezliğin derecesi ile artan düzeyde anemi gözlenmektedir. Bununla birlikte, KBH gelişmeden erken dönemde anemi görülen diyabetik olguların varlığı etiyolojide başka faktörlerin olabileceğini düşündürmüştür (5). Bunun nedenlerinden bir tanesi diyabetiklerde görülen eritropoetine yeterli yanıtın oluşmaması yani eritropoetin direncidir (6). Tip 2 diyabet tedavisinin temel taşı olan metforminin vitamin B12 düzeyini azaltarak megaloblasitk anemiye neden olduğu bilinmektedir (7). Diğer antidiyabetik ajanlardan glitazonlar ve DPP-4 (dipeptidil peptidaz-4) inhibitörleri ve diyabetiklerde antihipertansif ve albüminüriyi azaltmak amaçlı sıç̧a kullanılan ACEI (angiotensin converting enzyme inhibitors) ve ARB'lerin (angiotensin receptor blockers) de hemoglobin seviyelerini düşürdüğüne dair çalışmalar mevcuttur $(8,9)$. Ayrıca, diyabete bağlı gelişen kronik inflamasyon, eşlik eden otoimmun hastalıklar, insülin direnci de diyabetik hastalarda anemi ile ilişsili bulunan diğer nedenlerdir. Bununla birlikte, bu faktörlerin anemi gelişimindeki rolleri net bilinmemektedir. Diyabetin makrovasküler ve mikrovasküler komplikasyonları, diyabetli hastalarda önemli mortalite ve morbidite nedenidir. Anemide azalmış oksijen kapasitesine bağlı doku hipoksisi görülmektedir. Buna bağlı olarak anemik hastalarda kardiyovasküler mortalite oranı artmıştır (10). Bununla birlikte, diyabetik hastalarda aneminin mikrovasküler komplikasyonlarda progresyona neden olduğuna yönelik çalışmalar mevcuttur (11). Biz çalışmamızda diyabetik hastalarda anemi sıklığı, etiyolojisi ve makrovasküler ve mikrovasküler komplikasyonlarla birlikteliğini araştırmayı amaçladık.

\section{Gereç ve Yöntemler}

Retrospektif olarak planladığımız çalışmamıza 2019 yılında Eskişehir Osmangazi Üniversitesi Tıp Fakültesi Endokrinoloji Kliniği'nde yatarak tedavi gören 194 diyabet hastası alındı. Hastaların tam kan sayımı, böbrek fonksiyon testleri, Hbalc, vitamin B12, demir, demir bağlama kapasitesi, ferritin, folat düzeyleri kaydedildi. Hemoglobin düzeyi $13 \mathrm{~g} / \mathrm{dl}$ altında olan erkekler ve $12 \mathrm{~g} / \mathrm{dl}$ altında olan kadınlar anemik olarak kabul edildi. Vitamin B12 < 180 $\mathrm{pg} / \mathrm{ml}$ yetersiz olarak değerlendirildi.. Ferritin $<50 \mathrm{ng} / \mathrm{ml}$ demir eksikliği olarak kabul edildi (12). GFR, MDRD formülüne göre hesaplandı ve $\mathrm{GFH} \geq 90 \mathrm{ml} / \mathrm{dk}$ evre $1, \mathrm{GFH}=60-89$ $\mathrm{ml} / \mathrm{dk}$ evre $2, \mathrm{GFH}=30-59 \mathrm{ml} / \mathrm{dk}$ evre $3, \mathrm{GFH}$ $=15-29 \mathrm{ml} / \mathrm{dk}$ evre 4 ve $\mathrm{GFH}<15 \mathrm{ml} / \mathrm{dk}$ evre $5 \mathrm{KBH}$ olarak tanımlandı (13). Hastaların diyabet nedeniyle kullandıkları ilaçlar ve ACEI/ARB kullanımı kaydedildi. Hastalardan diyabetik retinopati, diyabetik ayak ülseri, KAH (koroner arter hastalığ 1 ), SVO (serebrovasküler hastalık) öyküsü olanlar hasta kayitlarından not edildi. Albümin düzeyi 24 saatlik idrarda $30 \mathrm{mg} /$ gün'ün altında olanlar normoalbüminürik, 30-300 $\mathrm{mg} / \mathrm{gün}$ olanlar mikroalbüminürik, $300 \mathrm{mg} /$ gün üzerinde olanlar makroalbüminürik olarak kabul edildi. Hematolojik hastalığ 1 olanlar, malignitesi olanlar ve gastrointestinal hastalığ 1 olanlar ve gestasyonel diyabet hastaları çalışmaya dahil edilmedi. Verilerin analizi IBM SPSS 21.0 programı ile yapıldı. Nicel değişkenlere ait özet değerler ortalama $+/$ - standart sapma ya da medyan (Q1- Q3) olarak, nitel değişkenler ise frekans ve yüzde olarak gösterildi. Nicel değişkenlerin normal dağılıma uygunluğu Shapiro Wilk testi ile araştırıldı. Normal dağılan iki grup karşılaştırmaları $t$ testi ile, dağılmayanlar ise Mann Whitney $U$ testi ile 
yapıldı. Nitel değişkenler arası ilişki ki kare analizleri ile incelendi. Analiz sonucu $\mathrm{p}<0.05$ olan durumlar anlamlı kabul edildi. Çalışmaya 12/05/2020 tarihinde etik kurul onayı alındı.

\section{Bulgular}

Çalışmamızda 194 diyabetik hastanın 127'si (\%65.5) kadın, 67'si (\%34.5) erkekti. Hastaların yaş ortalaması 55 (19-93), ortalama diyabet süresi 13yıl (0-36) ve ortalama Hbalc değeri 9.6 (5.1-17) idi. 64 hastada anemi gözlendi (\%33). Anemisi olan hastaların 41 (\%65.5)'i kadın, 23 (\%34.5) 'ü erkekti. Anemisi olan ve olmayan hastalarda kadın ve erkek dağılımı benzerdi $(p=0.89)$. Hastaların 84'ü (\%43.2) metformin kullanmaktayd. Metformin kullanan hastalarla vitamin B12 düşüklüğü arasında bir ilişki saptanmadı $(\mathrm{p}=$ 0.48). ACEİ ve ARB kullanımı ile anemi arasında ilişki gözlenmedi $(\mathrm{p}=1.0)$. Anemisi olan ve olmayan hastaların klinik özellikleri tablo halinde verilmiştir (Tablo 1).

Tablo 1. Anemisi olan ve olmayan hastaların klinik özellikleri

\begin{tabular}{lccc}
\hline & $\begin{array}{c}\text { Anemisi olan } \\
(\mathbf{n}=\mathbf{6 4})\end{array}$ & $\begin{array}{c}\text { Anemisi olmayan } \\
(\mathbf{n}=\mathbf{1 3 0})\end{array}$ & $\mathbf{p}$ \\
\hline Kadın n (\%) & $41(64.1)$ & $86(66.2)$ & 0.89 \\
Erkek n (\%) & $23(35.9)$ & $44(33.8)$ & 0.51 \\
Tip 1 n (\%) & $13(20.6)$ & $35(26.2)$ & \\
Tip 2 n (\%) & $50(79.4)$ & $96(73.8)$ & 0.10 \\
Yaş yıl & $58.7 \pm 16.3$ & $54.4 \pm 17.6$ & 0.63 \\
Metformin kullanan n (\%) & $26(40.6)$ & $58(44.2)$ & 0.75 \\
B12 eksikliği n (\%) & $6(10.9)$ & $6(7.8)$ & $<0.001$ \\
\hline Hb mg/dl & $11.02 \pm 1.12$ & $13.6 \pm 1.02$ & \\
\hline
\end{tabular}

Albüminüri ile anemi arasında anlamlı bir ilişki saptanmadı $(p=0.22)$. GFR 15 'in altında az sayıda hasta olması nedeniyle GFR'yi, $>90$,
60-90, 30-59, ve $<30$ olarak kategorize ettik ve GFR azaldıkça anemi sıklığının arttığını gördük ( $\mathrm{p}=0.003$; bkz. Şekil 1).

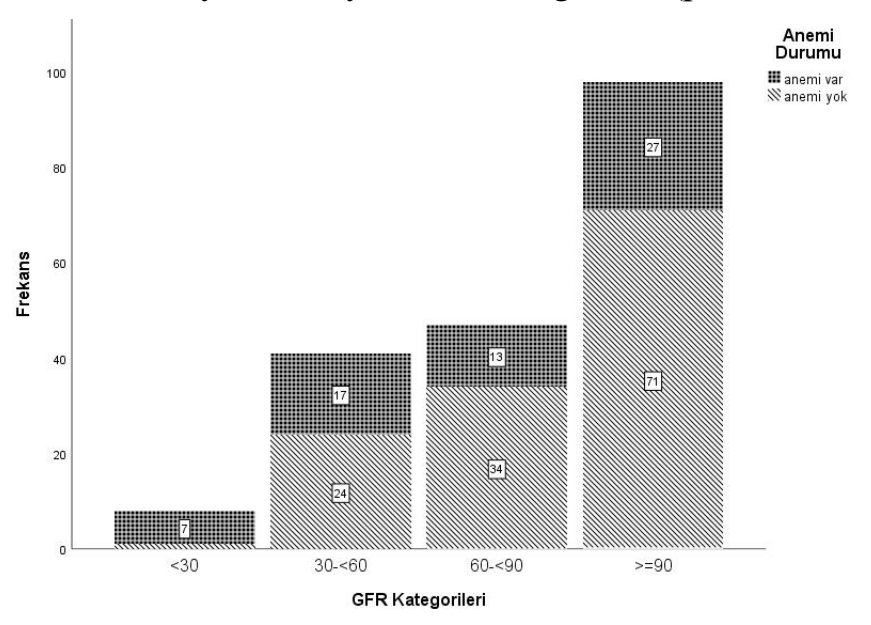

Hastaların \%10.3'ünde diyabetik ayak öyküsü mevcuttu. Diyabetik ayak öyküsü olan hastalarda anemi istatiksel düzeyde anlamlı olarak daha s1ktı $(p=0.004)$. GFR $>60 \mathrm{ml} / \mathrm{dk}$ olan hastalarda da diyabetik ayak öyküsü ile anemi arasında anlamlı ilişki saptandı $(\mathrm{p}=$ 0.004). Hastaların 64'ünde (\%33) herhangibir evrede diyabetik retinopati mevcuttu ve anemi ile ilişkisi saptanmadı $(\mathrm{p}=0.16)$. Diyabetik komplikasyonlar ve anemi ilişkisi tablo olarak verilmiştir (Tablo 2). 
Tablo 2. Diyabetik komplikasyonlar ile anemi ilişkisi

\begin{tabular}{lccc}
\hline & Anemisi olan & Anemisi olmayan & p \\
\hline KAH n (\%) & $15(24.2)$ & $27(21.3)$ & 0.78 \\
\hline SVO n (\%) & $4(6.7)$ & $7(5.5)$ & 0.74 \\
Diyabetik retinopati n (\%) & $26(48.1)$ & $38(35.5)$ & 0.16 \\
Periferilk nöropati n (\%) & $18(34)$ & $32(31.1)$ & 0.85 \\
Diyabetik ayak n (\%) & $13(21.3)$ & $7(5.8)$ & 0.004 \\
\hline
\end{tabular}

\section{Tartışma}

Çalışmamızda diyabetik hastalarda anemi oranı \%33'tü. Ülkemizde benzer çalışmalar olmamakla birlikte literatürde diyabetik hastalarda değișen oranlarda anemi bildirilmiştir (4,5). Brezilya'da yapılan bir çalışmada bizim çalışmamıza benzer bir oran (\%34.2) bulunmuştur (14). Normal böbrek fonksiyonu olan hastalarla yapilan bir çalışmada ise, diyabetik olmayanların \%2.7'si, diyabetik olanların \%10.8'i anemikti (15). Diyabete eşlik eden kronik böbrek hastalığ1 olan hastalarla yapılan çalışmada ise bu oran daha yüksekti (\%47.8) (16). Bu farklılık, çalışmaya alınan hastaların yaşı, kronik böbrek hastalığı varlığı, sosyoekonomik koşulları ve diyabet süresi gibi faktörlerle ilişkili olabilir.

Anemi morfolojisi büyük oranda normositerdi (\%67.2 normositer, \%38.2 mikrositer). Diyabet kronik inflamatuar bir durumdur. Proinflamatuar sitokin artışı ile EPO azalması, bozulmuş demir metabolizması, eritroid öncüllerde apoptozis ve buna bağlı gelişen normokrom normositer anemi kronik böbrek hastalığ 1 olmasa dahi diyabette beklenen bir bulgudur $(5,17,18)$. Anemisi olanlarin $\% 46$ 'sında beraberinde demir eksikliği vardı ve kadınlarda daha yüksekti. Tip 2 DM tedavisinde ilk seçenek olan metforminin B12 vitamini emilimini azaltabileceği ve megaloblastik anemiye yol açabileceği bilinmektedir. Metforminin bu etkisi, terminal ileumdan kalsiyum bağımlı B12 vitamini emilimini azaltmak, ince barsak motilitesini değiştirerek bakteriyel aşırı çoğalmayı tetiklemek ve IF (intrensek faktör) düzeylerini değiştirmek yoluyla olmaktadır. Metformin kullanan hastalarımızın \%11.8'inde B12 vitamini eksikliği vardı fakat megaloblastik anemi saptanmadı. Yapılan çalışmalarda metformin kullanan hastalarda \%5.8 ile \%24.5 arasında değişen oranlarda B12 vitamini eksikliği gözlenmiştir (19). Otuzbir çalışmayı içeren bir meta- analizde uzun süreli ve yüksek dozda metformin kullanımında B12 eksikliği anlamlı olarak artmıştır, ancak nöropati ve anemi gibi vitamin B12 eksikliği klinik bulgularında anlamlı artış gözlenmemiştir (20). Sağlık hizmetlerinin ulaşılabilirliği, hekimlerin sıkça kullandıkları metforminin bu etkisinden haberdar olarak vitamin B12 replasmanına özen göstermeleri, hastalar tarafindan multivitamin preparatlarının sik kullanılması gibi nedenlerle vitamin B12 eksikliğinin uzun dönem klinik bulgularına günümüzde pek rastlanmamaktadır.

Diyabetik hastalarda aneminin en önemli nedeni kronik böbrek hastalığıdır. Kronik böbrek hastalığında EPO eksikliğinin yanısıra demir eksikliği, eritrosit yaşam süresinin kısalması, kemik iliği fibrozisi, inflamasyon gibi faktörler anemiye katk1 sağlar. Çalışmamızda hastaların \%25'inin GFR'si 60'ın altındaydı. GFR düzeylerine göre gruplandırdığımızda GFR azaldıkça anemi oranının arttığını gördük. Diyabeti olan ve olmayan kronik böbrek hastalığı $(\mathrm{KBH})$ olan hastalarla yapılan bir çalışmada KBH'nin evresi arttıkça anemi prevelansının arttı̆̆ ve diyabeti olan grupta anemi eğiliminin daha fazla olduğu görülmüştür (21). Aneminin diyabetik hastalarda diyabetik olmayanlara göre daha fazla görülmesi, $\mathrm{KBH}$ olan hastalarda ise diyabeti olanlarda daha sik ve derin aneminin görülmesi diyabetiklerde anemi artışına neden olan başka faktörlerin araştırılmasına yol açmıştır. Bazı çalışmalar albüminüri düzeyi arttıkça aneminin arttı̆̆ını desteklemektedir. Hastalarımızdan anemisi olanların \%50'si normoalbüminürik, \%28'i mikroalbüminürik ve $\% 22$ 'si makroalbüminürikti. Diğer yandan, Bosmann ve arkadaşlarının proteinürisi olan tip 1 diyabet ve glomerulonefriti olan hastaları karşılaştıran çalışmasında her iki grupta tüm bireylerin 
proteinürisi olmasına rağmen tip 1 diyabet grubunda anemi daha sik ve EPO düzeyleri daha düşük gözlenmiştir. $\mathrm{Bu}$ durum, diyabetiklerde albüminüri dışındaki faktörlerin daha etkili olabileceğini düşündürmektedir.

Kronik hiperglisemiye maruziyetin anemiye neden olduğuna yönelik çeşitli mekanizmalar öne sürülmüştür. Bunlar ileri glikozilasyon son ürünlerinin eritrositlerin yaşam sürelerini kısaltmas1, EPO glikozilasyonu sonucu biyolojik aktivetisinde azalma, tübüler iskemiye bağl1 peritübüler fibroblastlarda hasar, EPO reseptör glikozilasyonu sonucu gelişen EPO direncidir $(6,22,23)$. Birçok çalışmada kötü glisemik kontrolü olan ve diyabet süresi uzun olan hastalarda anemiye daha sık rastlanmıştır $(5,18)$. Çalışmamızda Hbalc ve diyabet süresi ile anemi arasında bir ilişki bulamadık. Hasta grubumuzun büyük k1smını hiperglisemi veya hiperglisemiye bağlı komplikasyonlar nedeniyle yatarak tedavi görmekte ve kontrolsüz diyabeti olan hastalar oluşturmaktaydı. Bununla birlikte 1580 diyabetik hasta ile yapılan bir çalışmada da Hbalc ile anemi arasında anlamlı bir ilişki bulunamamıştır (24).

Diyabette hiperglisemiye bağlı artan serbest oksijen radikalleri, oksidatif stres artışına neden olmakta ve komplikasyonların gelişiminde rol oynamaktadır. Anemi ise doku hipokisi ile oksidatif stres artışına neden olur ve bu nedenle de diyabetik komplikasyonlarının ilerlemesini hızlandıracağı düşünülmüştür. Çalışmamızda, diyabetik ayak öyküsü olan hastalarda anemi sıklığı anlamlı olarak daha yüksekti. Kronik böbrek hastalığı olmayan grupta da aynı ilişki gözlendi. Prospektif vaka kontrollü bir çalışmada diyabetik ayak ülseri olan grupta anemi daha yüksek saptandı (25). Diyabetik

\section{KAYNAKLAR}

1. Saeedi P, Salpea P, Karuranga S, et al. Mortality attributable to diabetes in 20-79 years old adults, 2019 estimates: results from the International Diabetes Federation Diabetes Atlas. Diabetes Research and Clinical Practice. 2020;162, 108086.

2. Gauci R, Hunter M, Bruce DG, et al. Anemia complicating type 2 diabetes: prevalence, risk factors and prognosis. J Diabetes Complications. 2017;31:1169-74. ayak, nontravmatik ayak ampütasyonlarının yaklaşı 2/3'ünü oluşturan önemli bir morbidite ve mortalite nedenidir. Periferik arter hastalığ 1 , nöropati, basinca neden olan ayak deformiteleri ve travmalar diyabetik ayak için risk faktörleridir. Yakın tarihli bir çalışmada, diyabetik ayak yarası olan hastaların \%53.6'sinda anemi vardı ve anemi kötü yara iyileşmesi, amputasyon ve mortalite ile ilişkiliydi (26). Diğer yandan, Nijerya'da yapılan çok merkezli bir çalışmada, anemi ile alt ekstremite ampütasyonları arasında ilişski saptanmamıştır (27).

Literatürde diyabetik retinopatisi olan hastalarda anemi oranı daha yüksek saptanmış ve hipoksiye sekonder retinal hasar artış1 olabileceği düşünülmüştür (28), fakat bizim çalışmamızda ilişki gözlenmemiştir. Hastaların yaşları, hasta sayısı, diyabet süreleri gibi faktörler bu farklılığa neden olmuş olabilir.

Anemi KVH için bağımsız bir risk faktörü olarak kabul edilmektedir (29), renal hastalık varlığında bu risk daha da artmaktadır. Hastalarımızın \%21.6'sında iskemik kalp hastalığ 1 vardı ve anemi ile ilişkisi saptanmadı.

Sonuç olarak, çalışmamızda her 3 diyabet hastasının 1'inde anemi vardı. Anemi sıklığının artmış olması hastaların yatış gerektirecek kontrolsüz diyabetleri olmasindan kaynaklanabilir. Diyabetik hastalarda aneminin $\mathrm{KBH}$ ile ilişkisi ve tedavisi konusunda ortak bir görüş oluşmuşken, diğer komplikasyonların morbidite ve mortalite üzerine etkisi ve tedavi hedefleri konusundaki görüşler net değildir. Bununla birlikte mevcut verilerle diyabetik ayak sorunu olan olgularda anemi insidansinın fazla olmas1, bu grup hastalarda anemi tan1 ve tedavide erken davranılması açısından uyarıcı olabilir.

3. $\mathrm{Gu} \mathrm{L}$; Lou $\mathrm{Q}, \mathrm{Wu} \mathrm{H}$, et al. Lack of association between anemia and renal disease progression in Chinese patients with type 2 diabetes. $J$ Diabetes Investig. 2016;7:42-7.

4. Ezenwaka CE, Jones-Lecointe A, Nwagbara E, et al. Anaemia and kidney dysfunction in Caribbean type 2 diabetic patients. Cardiovasc Diabetol. 2008;7:25.

5. Thomas MC, MacIsaac RJ, Tsalamandris C, et al. Unrecognized anemia in patients with diabetes: a 
cross-sectional survey. Diabetes Care. 2003;26:1164-9.

6. Craig KJ, Williams JD, Riley SG, et al. Anemia and diabetes in the absence of nephropathy.Diabetes Care, 2005;28:1118-2.

7. Aroda VR, Edelstein SL, Goldberg RB, et al. Long-term metformin use and vitamin b12 deficiency in the diabetes prevention program outcomes study. $J$ Clin Endocrinol Metab. 2016;101:1754-61.

8. Berria R, Glass L, Mahankali A, et al. Reduction in hematocrit and hemoglobin following pioglitazone treatment is not hemodilutional in Type II diabetes mellitus. Clin Pharmacol Ther. 2007;82:275-81.

9. Vlahakos DV, Marathias KP, Madias NE. The role of the renin-angiotensin system in the regulation of erythropoiesis. Am J Kidney Dis, 2010;56:558-65.

10. Zeidman A, Fradin Z, Blecher A, et al. Anemia as a risk factor for ischemic heart disease.Isr Med Assoc J. 2004;6:16-8.

11. Thomas MC. Anemia in diabetes: marker or mediator of microvascular disease? Nat Clin Pract Nephrol. 2007;3:20-30.

12. Hoffman R, Benz Jr EJ, Silberstein LE, et al. Hematology: basic principles and practice, 7th Edition. Elsevier Inc. 2017.

13. Eckardt K-U, Berns JS, Rocco MV, et al. Definition and classification of CKD: The debate should be about patient prognosis-a position statement from KDOQI and KDIGO. Am J Kidney Dis. 2009;53:915-20.

14. Barbieri J, Fontela PC, Winkelmann ER, et al. Anemia in patients with type 2 diabetes mellitus. Anemia. 2015;2015:354737.

15. Grossman C, Dovrish Z, Koren-Morag N, et al. Diabetes mellitus with normal renal function is associated with anaemia. Diabetes Metab Res Rev. 2014;30:291-6.

16. Loutradis C, Skodra A, Georgianos P, et al. Diabetes mellitus increases the prevalence of anemia in patients with chronic kidney disease: a nested case-control study. World $J$ Nephrol. 2016;5:358-66.

17. Hong JH, Choi Y-K, Min B-K, et al. Relationship between hepcidin and GDF15 in anemic patients with type 2 diabetes without overt renal impairment. Diabetes Res Clin Pract, 2015;109:64-70.

18. Taderegew MM, Gebremariam T, Tareke AA, et al. Anemia and its associated factors among type 2 diabetes mellitus patients attending debre berhan referral hospital, north-east ethiopia: a crosssectional study. J Blood Med, 2020;11:47-58.

19. Shivaprasad C, Gautham K, Ramdas B, et al. Metformin usage index and assessment of vitamin b12 deficiency among metformin and nonmetformin users with type 2 diabetes mellitus. Acta Diabetol, 2020;57:1073-1080.
20. Yang W, Cai X, Wu H, et al. Associations between metformin use and vitamin b12 levels, anemia, and neuropathy in patients with diabetes: a metaanalysis. J Diabetes. 2019;11:729-743.

21. Loutradis C, Skodra A, Georgianos P, et al. Diabetes mellitus increases the prevalence of anemia in patients with chronic kidney disease: a nested case-control study. World $J$ Nephrol. 2016;5:358-366.

22. Bosman DR, Winkler AS, Marsden JT, et al. Anemia with erythropoietin deficiency occurs early in diabetic nephropathy. Diabetes Care. 2001;24:495-9.

23. Singh DK, Winocour $\mathrm{P}$, Farrington $\mathrm{K}$. Erythropoietic stress and anemia in diabetes mellitus. Nat Rev Endocrinol. 2009;5:204-10.

24. Alsayegh F, Waheedi M, Bayoud T, et al. Anemia in diabetes: experience of a single treatment center in Kuwait. Prim Care Diabetes. 2017;11:383-88.

25. Shareef AM, Ahmedani MY, Waris N. Strong association of anemia in people with abetic foot ulcers (DFUs): study from a specialist foot care center. Pak J Med Sci. 2019;35:1216-20.

26. Gezawa ID, Ugwu ET, Ezeani I. Anemia in patients with diabetic foot ulcer and its impact on disease outcome among Nigerians: results from the MEDFUN study. PLoS One. 2019;14:e0226226.

27. Ugwu E, Adeleye O, Gezawa I, Predictors of lower extremity amputation in patients with diabetic foot ulcer: findings from MEDFUN, a multi-center. J Foot Ankle Res. 2019;12:34.

28. Chung JO, Park S-Y, Chung DJ. Relationship between anemia, serum bilirubin concentrations, and diabetic retinopathy in individuals with type 2 diabetes. Medicine (Baltimore), 2019;98:e17693.

29. Sarnak MJ, Tighiouart H, Manjunath $G$, et al. Anemia as a risk factor for cardiovascular disease in the atherosclerosis risk in communities (ARIC) study. J Am Coll Cardiol. 2002;40:27-33. 